\title{
Epidemiological survey for goat leptospirosis in two distinct biomes in Northeastern
}

\section{Brazil}

\section{Levantamento epidemiológico da leptospirose caprina em dois biomas distintos do Nordeste do}

Brasil

Estudio epidemiológico de la leptospirosis caprina en dos biomas distintos en el Nordeste de Brasil

\section{Abstract}

Caprine breeding is a largely exploited activity in Brazil, with a herd of over 10 million goats concentrated mostly in the Northeast region, which contains $93.9 \%$ of the national herd. However, this region is affected by huge losses due to inappropriate management and illness occurrence, such as leptospirosis, a reproductive disease that causes economic and productive losses. Considering these previous statements, we aimed to determine the most frequent seroprevalence, serogroups and factors associated with the occurrence of leptospirosis in goats from different states and biomes of the Brazilian northeast and properly locate the disease throughout the region through the analysis of epidemiological questionnaires and geographic data. The samples were submitted to the Microscopic Agglutination Test (MAT) with a cutoff of 50. In addition, geographic data were analysed to create maps with epidemiological descriptions of the disease in the states. The total occurrence of seropositive animals was $19.93 \%(119 / 597), 18.92 \%$ $(35 / 185)$ in the state of Alagoas and 20.38\% (84/412) in Maranhão. The most common serogroups in these states were Autumnalis $(31.09 \%)$ and Icterohaemorrhagiae $(23.81 \%)$. Dividing the results, it was possible to observe a greater 
occurrence of the serogroup Autumnalis (42.86\%) Icterohaemorrhagiae (28.57\%) in the state of Alagoas, Caatinga biome, plus Autumnalis (26.19\%) and Icterohaemorrhagiae (23.81\%) in the state of Maranhão, Cerrado biome. It was proven that Leptospira sp. is present in both states and biomes analyzed, present in diverse areas as in vegetation and climate, warning preventive care towards the disease.

Keywords: Caatinga; Cerrado; Leptospira; Small ruminants; Public health; Zoonoses.

\begin{abstract}
Resumo
A caprinocultura é uma atividade largamente explorada no Brasil, com efetivo de mais de 10 milhões de caprinos, sendo o Nordeste região de destaque, com 93,9\% do rebanho nacional. Porém, ainda é uma região com grandes perdas causadas por manejo inadequado e ocorrência de enfermidades, dentre elas a leptospirose, doença da esfera reprodutiva que causa perdas produtivas e econômicas aos rebanhos. Dessa forma, objetivou-se determinar a soroprevalência, sorogrupos mais frequentes e os fatores associados à ocorrência da leptospirose em caprinos de estados com diferentes biomas no Nordeste brasileiro e geoespacializar a doença na região por meio da análise de questionários epidemiológicos e dados geográficos. As amostras foram submetidas ao teste de Soroaglutinação Microscópica (SAM) com ponto de corte 50. Além disso, dados geográficos foram analisados para construção de mapas com caracterização epidemiológica da leptospirose nos estados. A frequência de soropositivos foi de 19,93\% (119/597), sendo 18,92\% (35/185) no estado de Alagoas e 20,38\% (84/412) no Maranhão. Os sorogrupos mais frequentas para os estados foram Autumnalis (31,09\%) e Icterohaemorrhagiae $(25,21 \%)$. Segregando os resultados, foi possível observar a maior frequência do sorogrupo Autumnalis $(42,86 \%)$ e Icterohaemorrhagiae $(28,57 \%)$ no estado de Alagoas, bioma caatinga, e Autumnalis (26,19\%) e Icterohaemorrhagiae $(23,81 \%)$ no estado do Maranhão, bioma do cerrado. Constatou-se que a Leptospira sp. está presente nos estados analisados, tanto no bioma Caatinga quanto no Cerrado, estando presente em áreas de características diversificadas quanto a vegetação e clima, o que gera alerta para os cuidados preventivos em relação a doença.
\end{abstract}

Palavras-chave: Caatinga; Cerrado; Leptospira; Pequenos ruminantes; Saúde pública; Zoonoses.

\title{
Resumen
}

La cría de cabras es una actividad ampliamente explorada en Brasil, con más de 10 millones de cabras, siendo el Nordeste una región destacada, con el 93,9\% del rebaño nacional. Sin embargo, todavía es una región con grandes pérdidas por manejo inadecuado y la ocurrencia de enfermedades, entre ellas la leptospirosis, enfermedad de la esfera reproductiva que ocasiona pérdidas productivas y económicas a los rebaños. Así, el objetivo fue determinar la seroprevalencia, los serogrupos más frecuentes y los factores asociados con la ocurrencia de leptospirosis en cabras de estados con diferentes biomas del noreste de Brasil y geoespacializar la enfermedad en la región a través del análisis de cuestionarios epidemiológicos y datos geográficos. Las muestras fueron sometidas a la Prueba de Soroaglutinación Microscópica (SAM) con un punto de corte de 50. Además, se analizaron datos geográficos para construir mapas con caracterización epidemiológica de leptospirosis en los estados. La frecuencia de individuos seropositivos fue de 19,93\% (119/597), 18,92\% (35/185) en el estado de Alagoas y 20,38\% (84/412) en Maranhão. Los serogrupos más frecuentes para los estados fueron Autumnalis (31,09\%) y Icterohaemorrhagiae $(25,21 \%)$. Segregando los resultados, fue posible observar la mayor frecuencia del serogrupo Autumnalis $(42,86 \%)$ y Icterohaemorrhagiae $(28,57 \%)$ en el estado de Alagoas, bioma caatinga, y Autumnalis (26,19\%) y Icterohaemorrhagiae (23,81\%) en el estado de Maranhão, el bioma del cerrado. Se encontró que Leptospira sp. está presente en los estados analizados, tanto en los biomas de Caatinga como en Cerrado, estando presente en áreas con diversas características como vegetación y clima, lo que genera un alerta para la atención preventiva en relación a la enfermedad.

Palabras clave: Caatinga; Cerrado; Leptospira; Pequeños rumiantes; Salud pública; Zoonosis.

\section{Introduction}

Breeding of small ruminants is a highly exploited activity in tropical countries. Brazil has a herd of 10,696,664 goats, and the Northeast region has $93.9 \%(10,047,755)$ of animals according to IBGE (2019). Most of the productive systems aim at subsistence, presenting problems such as lack of technical assistance, management issues and low level of producer organization, financially compromising the activity due to low productivity of the herd and causing deficiencies generated mainly by infectious diseases (Sousa, 2007; Fernandes, 2009; Guilherme et al., 2017).

Among the infectious diseases that affect goats, leptospirosis must be highlighted due to its high level of spread, causing miscarriages and birth of weak and premature offspring, in addition to the decrease in milk production (Ellis, 2015). Despite these facts, diagnosis remains a challenge because the infection is often subclinical and presents varied symptoms (Faine et al., 1999, Martins \& Lilenbaum, 2014, Da Costa et al., 2019).

Goats are less susceptible to leptospirosis than other species, such as cattle and dogs (Martins \& Lilenbaum, 2014), 
presenting fewer clinical signs; however, they end up hosting the agent and even spreading the disease reproductively in the semiarid climate, as rated by Silva et al. (2018) and Nogueira et al. (2020) in research with sheep, this causes the bacteria to remain in the environment, posing a risk to the population and animals, especially in intercropping.

High levels of temperature and drought occurring in areas such as the northeast region physiologically affect the herd, negatively weighing its production and breeding (Viana et al., 2012; Souza et al., 2015). Another important aspect to be considered is the ecological diversity dwelling in a continental-sized country such as Brazil, which owns several different zones, the biomes. The Northeast region follows this same characteristics, containing four biomes: Mata Atlântica, Caatinga, Cerrado and a small part of Amazônia (Brasil, 2020), expressing different soil and climate characteristics that can influence the occurrence of leptospirosis.

Thus the aim of this survey was to determine the indicators that characterize the epidemiological situation regarding leptospirosis in goats in two distinct biomes in Northeastern Brasil.

\section{Methodology}

This survey was submitted and approved by Ethics and Research Committee (ERC) of Centro de Saúde e Tecnologia Rural (CSTR) of Universidade Federal de Campina Grande (UFCG) under protocol number 103/2017.

The studies were conducted under the selection of a considerable sample of goats from breedings in the states of Maranhão and Alagoas, dwelling in the northeast region of Brazil, a region that concentrates the majority of goat breedings. The minimum number of animals was defined using the formula for simple random (Thrusfield, 2007), taking into account the following parameters: prevalence of seropositive animals of 50\%, to maximize the sample, sampling error of 5\% and $95 \%$ confidence level. For these parameters it would be necessary to have a sample of 385, however, a final sample consisted of 597 animals, of both sexes, youth and adults (6 to 12 months), from regions that concentrate a significant number of the herd in the region. Breeders cooperated willingly. Data insertion was performed through non-probabilistic sampling, randomly sorting previously selected sites and lists provided by breeders associations, state agencies, secretary of agriculture and SEBRAE.

The number of samples selected was determined individually for each herd, aiming to detect the occurrence of infections. Calculations were made according to the formula commonly applied to epidemiological veterinarian investigations (Thrusfield, 2007):

$$
\mathrm{n}=\left[1-(1-\mathrm{p})^{1 / \mathrm{d}}\right] \times(\mathrm{N}-\mathrm{d} / 2)+1
$$

Where $\mathrm{n}$ is the number of samples; $\mathrm{p}$ is the probability of detection of at least one seropositive animal; $\mathrm{N}$ is the number of animals in the herd; and $d$ is the number of seropositive animals.

The probability of detection of at least one seropositive animal in a herd was determined at $95 \%(\mathrm{p}=0,95)$, and the number of seropositive animals at each heard (d) was calculated assuming a prevalence of herd of $16.19 \%$ (Alves et al., 1996). On herds of under 20 animals, all were sampled, and when the number surpassed 20, sampling was performed using only 20 specimens.

The samples were collected in six cities of Alagoas (Delmiro Gouveia, Mata Grande, Poço das Trincheiras, Santa do Ipanema, Canapi e São José das Taperas), located in regions of Sertão and Agreste of the state, in the caatinga biome, containing 12,080 goats distributed through 2,102 establishments (IBGE, 2017). As in Maranhão, the samples were collected in eight cities (Caxias, Buriti, Brejo, Magalhães de Almeida, Barreirinhas, Primeira Cruz, Santo Amaro e Vargem Grande) in the north and east of the state, fully located at the Cerrado biome, where 35,858 animals dwell in 2,102 establishments (IBGE, 2017). 
Field activities included blood collection and epidemiological questionnaires with further mailing of samples to serological tests. Blood samples were drawn out of young and adult goats, $8 \mathrm{ml}$ per individual, through puncture of the jugular vein with disposable needles and vacuum tube (without anticoagulants) with $8.5 \mathrm{ml}$ capacity. After draining the serum, it was transferred to microtubes and frozen at $-20^{\circ} \mathrm{C}$ until the serological test.

The Microscopic Agglutination Test (MAT), a serologic test recommended for the diagnosis of leptospirosis, was performed according to the OIE (2014). The antigens used were manufactured by Pasteur Institute in France and provided by the Veterinarian Bacteriology Laboratory of Universidade Federal Fluminense in Niterói, Rio de Janeiro, Brasil (Leptospira interrogans: Copenhageni, Bratislava, Canicola, Grippotyphosa, Hardjoprajitno, Kennewicki, Pomona, Pyrogenes, Icterohaemorrhagiae, Hebdomadis, Wolffi; Leptospira borgpeterseni: Autumnalis, Ballum, Castellonis, Javanica, Mini, Tarassovi; Leptospira santarosai: Guaricura, Canalzoni; Leptospira kirschneri: Cynopteri, e Leptospira noguchii: Lousiana, Panama; Leptospira weilli: Celledoni). The sera that presented $50 \%$ or more agglutination at the indicated dilution were entitled in a series of geometric dilutions at reason two, with a cutoff of 50. The titer of the serum was the reciprocal of the greater positive dilution.

For the analysis of factors associated with the seropositivity the procedure of transversal studies (Thrusfield, 2007) was used, realized with data provided by the epidemiological questionnaires.

A questionnaire containing 49 discursive and objective questions was elaborated and applied to obtain information about the profile of productors and the technological characteristics of the property, the structure and composition of the herd and the production management and sanitary aspects of the herd. The variables analyzed are provided in supplementary material.

To identify factors associated with seropositivity, a univariable analysis was initially performed, in which each independent variable was submitted to an analysis of association with the dependent variable (seropositivity). Variables with a value of $\mathrm{P} \leq 0.2$ in the Chi-square test were selected for a multivariable analysis using Poisson regression tests. Collinearity among independent variables was verified through an analysis of correlation; for variables with stronger collinearity (correlation coefficient $>0.9$ ), one of the two variables was excluded from the multiple analysis according to the biological plausibility. To evaluate the adjustment of the regression model, Pearson's Chi-square test was used. The level of significance adopted for the multiple analysis was 5\%, and the analyses were performed in environment R (R Core Team, 2019) with "Epi”" packages (Carstensen et al., 2019), “Sandwich" (Berger et al., 2017), and "lmtest” (Zeileis \& Hothorn, 2002).

For the spatial distribution analysis of the seroprevalence of Leptospira sp. and of the serogroups in the states, the geographic coordinates of each property were registered and analyzed through the software Google Earth Pro and used in the construction of geographic maps with the usage of the software QGIS 3.12.2.

\section{Results}

Out of 597 sampled animals, 119 (19.93\%) were seropositive to Leptospira sp. The occurrence in Alagoas (Caatinga biome) was 18.92\%, with 35 sero reagent animals, while Maranhão (Cerrado biome) presented 20.39\%, 84 sero reagent animals, not presenting a significant difference as to the positivity as to the positivity between the biomes $(\mathrm{p}=0.1740)$.

The most frequent serogroups were Autumnalis (31.09\%) and Icterohaemorrhagiae (25.21\%), with titers from 50 to 1600, sero reagent animals to the serogroups Canicola, Pomona, Javanica, Pyrogenes, Serjoe, Grippotyphosa, Pomona and Australis (Table 1). In the Caatinga biome, state of Alagoas, the serogroup Autumnalis represented $42.86 \%$ of the positive ones and Icterohaemorrhagiae represented $28.57 \%$. In the Cerrado, the occurrences to Autumnalis and Icterohaemorrhagiae were $26.19 \%$ to the former and $23.81 \%$ to the latter. 
Table 1 - Serogroups of Leptospira sp. with the largest prevalence and respective titers in goats in the states of Maranhão and Alagoas, using a cutoff of 1:50 on MAT.

\begin{tabular}{ccccccccc}
\hline \multirow{2}{*}{ State } & Serogroups & \multicolumn{9}{c}{ Titers } & \multirow{2}{*}{ Total (\%) } \\
\cline { 3 - 7 } & & 50 & 100 & 200 & 400 & 800 & 1600 & \\
\hline \multirow{3}{*}{ Maranhão } & Javanica & - & 2 & - & - & - & - & $2(2.38)$ \\
& Icterohaemorrhagiae & 9 & 7 & 2 & 1 & - & 1 & $20(23.81)$ \\
& Australis & 5 & 5 & 6 & 3 & - & - & $19(22.62)$ \\
& Autumnalis & 18 & 2 & 2 & - & - & - & $22(26.19)$ \\
& Sejroe & 1 & 2 & - & - & - & - & $3(3.57)$ \\
& Grippotyphosa & 1 & 3 & 2 & 1 & - & - & $7(8.33)$ \\
& Pomona & - & 4 & 2 & 2 & 3 & - & $11(13.10)$ \\
& Canicola & - & - & 1 & - & - & - & $1(2.86)$ \\
& Icterohaemorrhagiae & 4 & 3 & 1 & 1 & - & 1 & $10(28.57)$ \\
& Pomona & 1 & - & - & - & - & - & $1(2.86)$ \\
& Australis & 2 & - & 1 & - & - & - & $3(8.57)$ \\
& Autumnalis & 12 & 1 & 2 & - & - & - & $15(42.86)$ \\
& Grippotyphosa & 3 & - & - & - & - & - & $3(8.57)$ \\
& Pyrogenes & - & - & - & 1 & 1 & - & $2(5.71)$ \\
\hline
\end{tabular}

Source: Authors.

Figure 1 shows the frequency of goats seropositive to Leptospira sp. in each municipality studied in the state of Alagoas, the Caatinga biome, comparing them using the color scale used. In addition, it is possible to observe the most frequent serogroups in each municipality and their respective frequency through the diameter of the circumference. Figure 2 shows the frequency of goats seropositive to Leptospira sp. in each municipality studied in the state of Maranhão, the Cerrado biome, comparing them using the color scale used. In addition, it is possible to observe the most frequent serogroups in each municipality and their respective frequency through the diameter of the circumference. 
Figure 1 - Occurrence of goats sero reagent to Leptospira sp. per county and property and most frequent serogroups in the state of Alagoas, Brazilian Northeast, 2020.

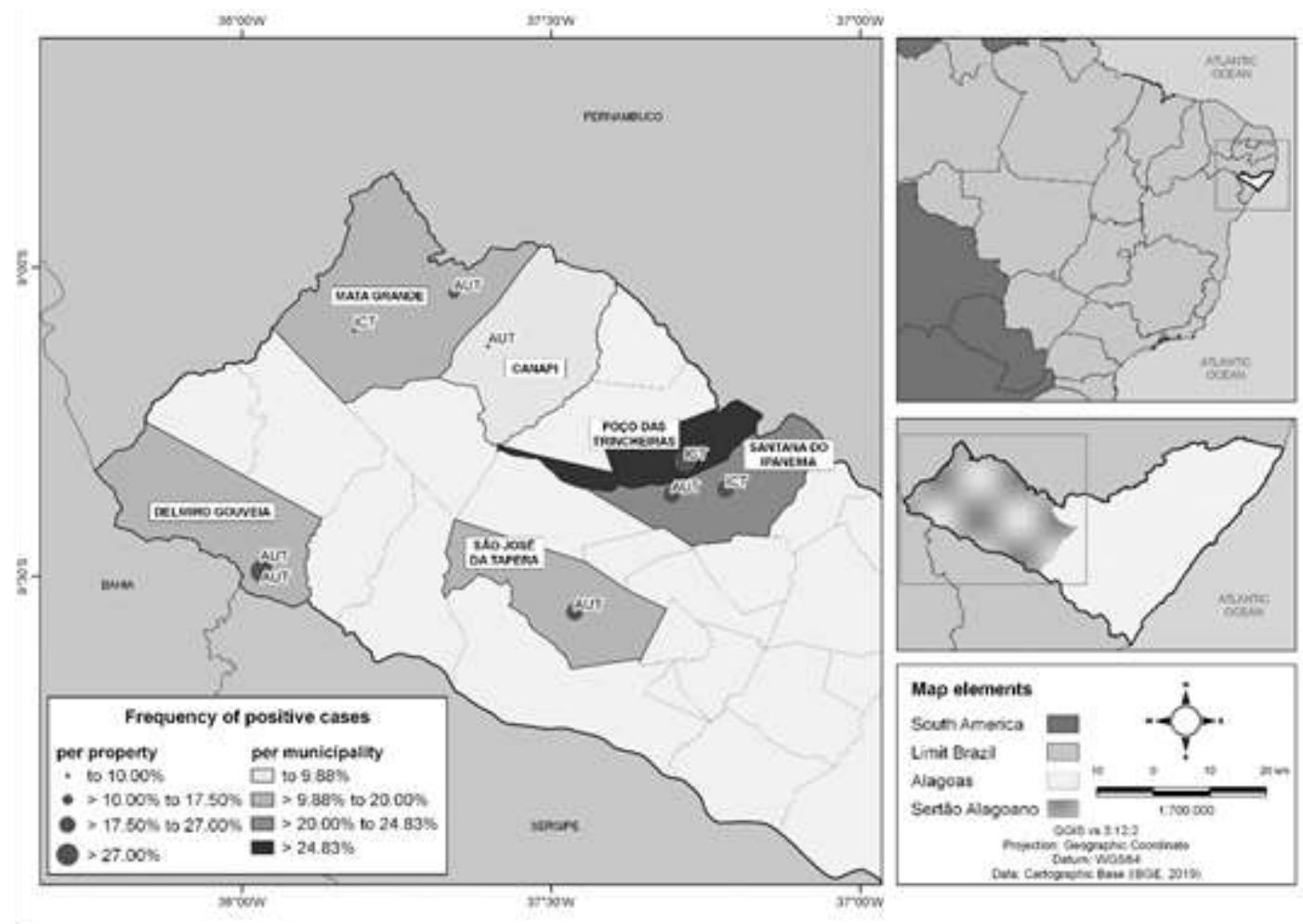

Source: Authors.

Figure 2 - Occurrence of goats sero reagent to Leptospira sp. per county and property and most frequent serogroups in the state of Maranhão, Brazilian Northeast, 2020.

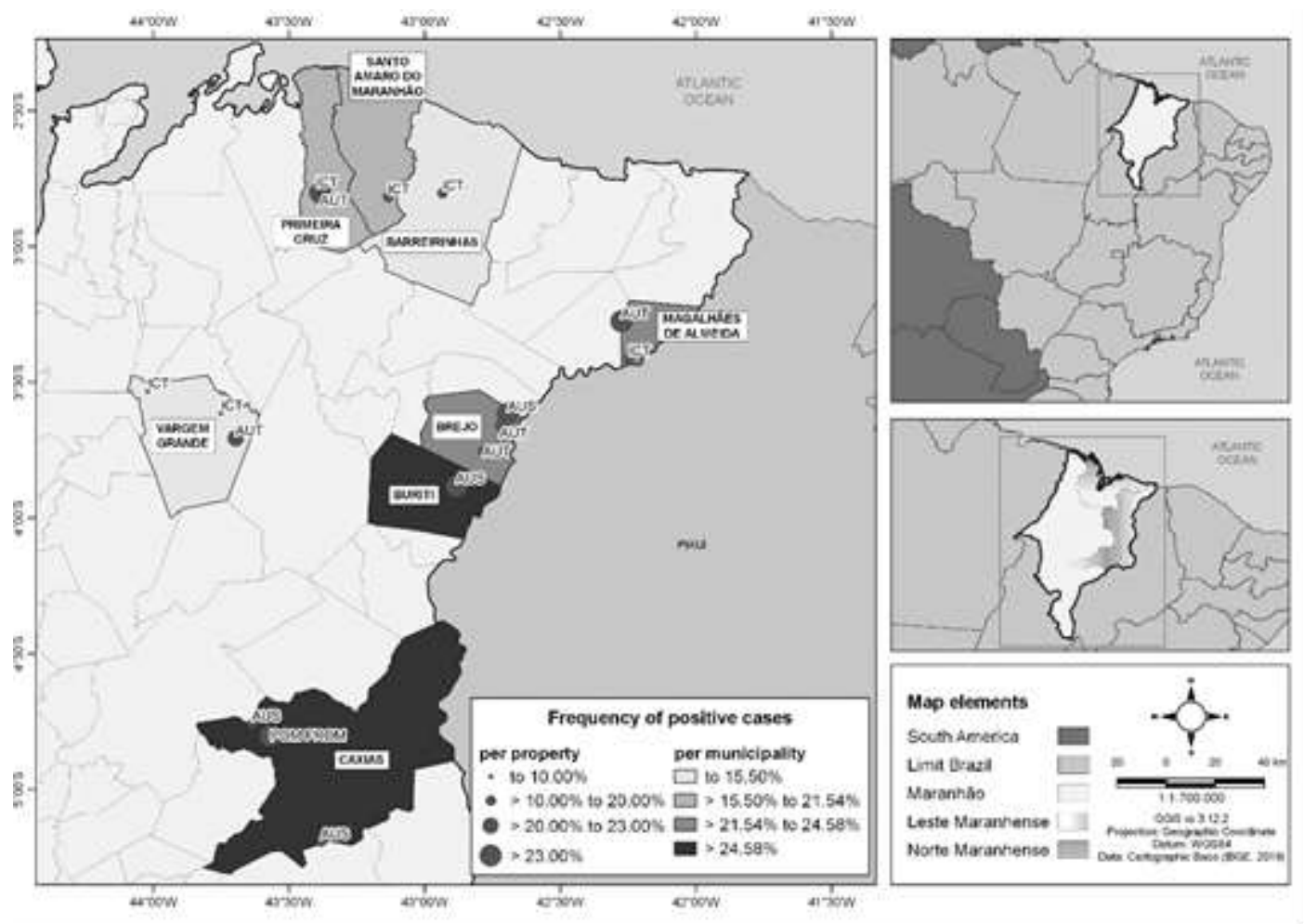

Source: Authors. 
The county with most occurrences in Alagoas was Poço das Trincheiras (Caatinga), with 30\% positivity, followed by Santa Ipanema, with $23.1 \%$ seropositive animals. In Maranhão (Cerrado), the highest occurrence occurred in Caxias, with $32.2 \%$, followed by Buriti, with $25 \%$. In both states, the occurrence of seropositivity in properties varies from $6 \%$ to $65 \%$, as shown on Figures 1 and 2. In Caxias, the property with the highest seroprevalence was found, and in Mata Grande, the smallest occurrence was observed.

The significant factors in the univariate analysis $(P \leq 0.2)$ are described in Table 2 . The factors associated with seropositivity to Leptospira spp. are demonstrated in table 3, and the ones that showed relevance were age $(P<0.001)$ and race $(P=0.012)$, in addition to not laying lime at the entry of the pens $(P=0.023)$ and the production of food reserves to the dry period $(P<0.001)$.

Table 2 - Univariate analysis with the selected variables $(\mathrm{P} \leq 0.2)$ to the logistic regression.

\begin{tabular}{|c|c|c|c|c|}
\hline Variable & Category & $\begin{array}{c}\text { Total } \\
\text { number of } \\
\text { animals }\end{array}$ & $\begin{array}{c}\text { Total number of } \\
\text { positive } \\
\text { animals }(\%)\end{array}$ & $P$ \\
\hline \multirow[t]{2}{*}{ Breeder's age range } & Younger than 62 & 459 & $83(18.1)$ & \multirow{2}{*}{0.051} \\
\hline & $>62$ anos & 138 & $36(26.1)$ & \\
\hline \multirow[t]{2}{*}{ Animal's age } & Young & 212 & $17(8)$ & \multirow{2}{*}{0.000} \\
\hline & Adult & 385 & $102(25.5)$ & \\
\hline \multirow[t]{2}{*}{ Water quality } & $\mathrm{Bad}$ & 139 & $34(24.5)$ & \multirow{2}{*}{0.146} \\
\hline & Good & 458 & 85 (18.6) & \\
\hline \multirow[t]{2}{*}{ Other incomes in the family? } & No & 150 & $40(26.7)$ & \multirow{2}{*}{0.024} \\
\hline & Yes & 447 & $79(17.7)$ & \\
\hline \multirow[t]{2}{*}{ Production's final destination } & Meat & 461 & $99(21.5)$ & \multirow{2}{*}{0.088} \\
\hline & Mixed & 136 & $20(14.7)$ & \\
\hline \multirow[t]{2}{*}{ Breed } & Non definite breed & 443 & $74(16.7)$ & \multirow{2}{*}{0.001} \\
\hline & Definite breed & 154 & $45(29.2)$ & \\
\hline \multirow[t]{2}{*}{ Is there lime on the entrances? } & No & 349 & $79(22.6)$ & \multirow{2}{*}{0.061} \\
\hline & Yes & 248 & $40(16.1)$ & \\
\hline \multirow{2}{*}{$\begin{array}{l}\text { Installation's cleaning } \\
\text { frequence }\end{array}$} & Daily/Weekly/Quarterly/Monthly & 287 & $50(17.4)$ & \multirow{2}{*}{0.152} \\
\hline & Doesn't perform/More than a month & 310 & $69(22.3)$ & \\
\hline \multirow[t]{2}{*}{ Is concentrated provided? } & No & 145 & $36(24.8)$ & \multirow{2}{*}{0.095} \\
\hline & Yes & 452 & $83(18.4)$ & \\
\hline \multirow{2}{*}{$\begin{array}{l}\text { Is food stored to the drought } \\
\text { period? }\end{array}$} & No & 319 & $51(16)$ & \multirow{2}{*}{0.010} \\
\hline & Yes & 278 & $68(24.5)$ & \\
\hline
\end{tabular}


Table 3 - Factors associated with leptospirosis in goats from the states of Alagoas and Maranhão, determined by regression.

\begin{tabular}{ccccccc}
\hline Variable & $\begin{array}{c}\text { Coefficient } \\
(\beta)\end{array}$ & $\begin{array}{c}\text { Standard } \\
\text { error }\end{array}$ & Wald & $\begin{array}{c}\text { Odds ratio } \\
(\mathrm{OR})\end{array}$ & 95\% CI for OR & P-value \\
\hline Animal's age (adult) & 1.47 & 0.29 & 5.07 & 4.32 & $2.45-7.61$ & $<0.001$ \\
Breed (DB) & 0.68 & 0.27 & 2.50 & 2.00 & $1.17-3.43$ & 0.012 \\
Lime on the pens (Não) & 0.62 & 0.27 & 2.28 & 1.82 & $1.07-3.08$ & 0.023 \\
Store food (Sim) & 0.92 & 0.24 & 3.75 & 2.36 & $1.48-3.78$ & $<0.001$ \\
\hline
\end{tabular}

Goodness of fit test (Hosmer and Lemeshow test): Chi-square $=1.98$; degrees of freedom $=8 ; \mathrm{P}=0.982$. Source: Authors.

\section{Discussion}

The biomes studied reveal peculiarities to each region. In this study, it was possible to observe seropositivity statistically equal in states with different geographic characteristics, as Maranhão is located on the transition between Cerrado and Amazônia, presenting a great variety of ecosystems and biodiversity, Alagoas presents annual precipitation of $400 \mathrm{~mm}$ to $2200 \mathrm{~mm}$ (Barros et al., 2012), and the cities studied have semi-arid characteristics and smaller levels of precipitation. This corroborates the thesis that leptospirosis is no longer a disease of flooded areas and that it might be present in many herds in northeast Brazil, even in hostile environments, drought periods, capable of surviving even in the presence of higher titers of serology in dry periods, needing active surveillance and reinforcing in the acting of preventive veterinary medicine, due to the zoonotic potential of the disease and the laboral hazard in the acting of professionals such as vets, breeders, and slaughterhouse workers (Dorjee et al., 2008; Adler \& De La Peña Moctezuma, 2010; Nogueira et al., 2020).

It is important to remember that in this period, the northeast region of Brazil suffered from a long drought season, and this climatic condition can lower the rates of the disease due to its characteristic of humid area occurrence and the transmissibility characteristics of leptospirosis can influenced by climatic characteristics, as suggested by Costa et al. (2016); however, leptospirosis continued to affect both biomes despite the adverse situation because leptospirosis can be influenced by many factors, such as the region, which has varied levels of temperature, humidity, topography, precipitation, and the reservoirs involved, wild (foxes, possums, rodents) and/or domestic animals (Alves et al., 2000), in addition to the possible existence of alternative routes of transmission that are less dependent on environmental factors (Pimenta et al., 2019).

There was no significant difference among the occurrences found in the biomes $(\mathrm{p}=0.740)$, even with differences breeding systems or susceptibility to the studied breedings, such as humidity, as the Cerrado presents a great number of springs and watersheds, such as São Francisco, compared to Caatinga, presenting lower humidity and long droughts (Leal et al., 2005; Ribeiro et al., 2005).

In Maranhão (Cerrado), the breeding with the highest occurrence (65\% seropositivity) was surrounded by green areas and many water sources, highlighting the importance of water to the cycle of the disease once the animals contract the illness through direct contact with urine and contaminated tissues or indirectly through contact with contaminated water or infected urine (Adler et al., 2011).

At some properties, a great presence of deforested area was noticed, as in Delmiro Gouveia, Alagoas, in the Sertão, with the highest occurrence of $38 \%$, which warns to the diversity of biomes in which the disease can spread, once that Sertão presents semi arid characteristics, inserted in the Caatinga biome, and a hydric deficit that can surpass $500 \mathrm{~mm}$ (Barros et al., 2012). The smallest occurrence was observed in Mata Grande, far west characterized by the highest level of humidity (Correia, 2012). 
This study found high occurrences in Icterohaemorrhagiae and Autumnalis, with $25.21 \%$ occurrences in the former and $31.09 \%$ occurrences in the latter, which is a recurrent fact in studies related to animals in the Northeast (Costa et al., 2017; Moraes et al., 2019). This is an important fact, as it brings worries to human and animal health, once leptospirosis can also occur in occupational form, and these serogroups are important to the disease cycle in humans, especially to those in contact with the animals and their fluids, such as agricultors, slaughterhouse workers and veterinarians (Dorjee et al., 2008; Adler \& De La Peña Moctezuma, 2010), and it was observed the presence of the disease in both biomes, despite their differences in soil and climate, suggesting a relation between the region studied and the occurrence of these serogroups.

In both biomes, but especially in Caatinga, there were degraded and deforested areas, favoring the presence of wild animals and rodents. In addition, there was a prevalence of the serogroups Autumnalis and Icterohaemorrhagiae, inherent to these species. It is known that rodents have an importance in the spread of leptospirosis, as synanthropic rodents such as the mouse (Rattus norvegicus) are maintenance hosts to the Icterohaemorrhagiae serogroup and wild rodents to the autumnalis (Faine et al., 1999; Spickler \& Leedom Larson, 2013).

The occurrence of sero reagent animals to the Autumnalis serogroup is and important fact, and it draws attention, sinde this seropositivity is not included in the vaccines commercialized, rising concerns around the security of the animals and evidentiate the need of studies that provide a better description of the disease in specific areas and the need of inclusion of these sero varieties to the production of vaccines (Higino et al., 2010).

The Pomona serogroup, highly spread through Maranhão, was found in $65 \%$ of a property in the state and is usually found in suines without clinical symptomatology (Romero-Rivas et al., 2013; Adler \& De La Peña Moctezuma, 2010), and the appearance in goats of this study may indicate contact between the species, something frequent which was noticed in the analyzed properties.

The presence of sero reagent animals to the Grippotyphosa and Australis serogroups may be related to the studied areas, as these groups infect wild animals, such as racoons and possums to the Grippotyphosa (Salaberry et al., 2011; Lenharo et al., 2012), and some properties analyzed in this study belong to rural areas and deforested regions, which favor contact between domestic and wild animals and a possible infection. It is important to highlight that these serogroups occurred in both biomes, suggesting this similarity to the serogroups even in environments with different characteristics.

The age and breed of the animal, in addition to the displacement of lime on the entrance of the pens and the elaboration of food supplies to the drought period, were considered factors associated with positivity.

Adult animals, especially reproductors with a definite breed, were more susceptible to the seropositivity of leptospirosis when compared to young animals and animals without a definite breed in that order. This can be explained by the survival time of the adult animals, which causes a larger exposure to the agent, in addition to the rusticity and larger resistance of the animals with indefinite breeds facing the ones with a definite breed pattern, as confirmed by the studies of Santos et al. (2012) \& Silva et al. (2012) \& verified by Costa et al. (2019), when stating that mixed animals show greater resistance to infections than the animals of breed.

The usage of lime $(\mathrm{CaO})$ in the structures of the pens is a common measure by breeders of domestic animals, as the substance has proven insecticide and bactericide properties, being indispensable for cleaning and disinfection (Kich, 2005; Daipra et al., 2009; Wolf et al., 2014). Considering this, not using this substance may result in biological risks, as was noticed in this study, as animals of properties that neglected this practice presented higher levels of seropositivity of Leptospira spp.

The production of alimentar supplies as an associated factor may be explained through the management and storage of these nourishments, as they attract rodents, especially those related to the Icterohaemorrhagiae and Autumnalis serogroups, more frequently in this study, as previously discussed, since these animals are extremely important to the chain of transmission of the disease and immune to the clinical disease, in addition to acting as healthy hosts, harboring the agent and pouring it to 
the environment through the urine, contaminating food, water and tools used in the management of the herds, as feeders and water sources (Faine et al., 1999; Spickler \& Leedom Larson, 2013; Paes, 2016). In addition, breeders who store food usually feed their animals intensely, using feeders that increase the contact between animals, which is different from the animals who feed from pasture, easing the spread of the agent.

\section{Conclusion}

Based on this, it was concluded that Leptospira sp. is present in goats studied in the states of Maranhão and Alagoas and that there is a similarity as to the serogroups involved in the disease patogeny in theses regions, varying only in the frequence in which they are found, even in these states that are located in different biomes, as Maranhão is located in the transition zone between Amazônia and Cerrado, which gives a great variety of ecosystems and biodiversity, and Alagoas to the Caatinga biome. Moreover, it is possible to conclude that leptospirosis is spread through areas with diverse characteristics, not being a disease restricted to flooded areas or with specific vegetation, which warns preventive care towards the disease, considering its effect on the productive chain and public health, since it is a zoonotic illness. In the end, it is suggested that more research be carried out on the characteristics of leptospirosis in more states in the region for better knowledge and reliable characterization of the disease in this area so important for goat farming and for the economy.

\section{Acknowledgments}

The authors would like to thank Conselho Nacional de Desenvolvimento Científico e Tecnológico / Ministério da Agricultura Pecuária e Abastecimento for the financial support of the research through Notice 64/2008. We also would like to appreciate the Departamento de Sanidade Animal, Embrapa Caprinos e Ovinos, Sobral, CE, for the opportunity and cooperation on the research.

\section{References}

Adler, B., \& De La Peña Moctezuma, A. (2010). Leptospira and leptospirosis. Veterinary Microbiology, 140 (3), 287-296

Adler, B., Lo. M., Seemann, T., \& Murray, G. L. (2011). Pathogenesis of leptospirosis: The influence of genomics. Veterinary Microbiology, 153 (1-2), 73 81

Alves, C. J., Andrade, J. S. L., Vasconcellos, S. A., Morais, Z. M., Azevedo, S. S., \& Santos, F. A. (2000). Avaliação dos níveis de aglutininas anti-Leptospira spp. em cães no município de Patos-PB, Brasil. Revista Brasileira de Ciência Veterinária, 7 (2), 17-21

Alves, C. J., Vasconcellos, S. A., Camargo, C. R. A., \& Morais, Z. M. (1996). Influência dos fatores ambientais sobre a proporção de caprinos soro-reatores para a leptospirose em cinco centros de criação do estado da Paraíba, Brasil. Arquivos Instituto Biológico, 63 (2), 11-19

Barros, A. H. C., Filho, J. C. de A., Silva, A. B. da, \& Santiago, G. A. C. F. (2012). Climatologia do estado de Alagoas. Boletim de Pesquisa e Desenvolvimento - Embrapa Solos, $32 \mathrm{p}$

Berger, S., Graham, N., \& Zeileis, A. (2017). "Various Versatile Variances: An Object-Oriented Implementation of Clustered Covariances in R". Technical Report 2017-12, Working Papers in Economics and Statistics, Research Platform Empirical and Experimental Economics, Universität Innsbruck. em: <http://EconPapers.RePEc.org/RePEc:inn:wpaper:2017-12>.

Brasil. Ministério do Meio Ambiente, M. M. A, BRASIL. Biodiversidade Brasileira. 2020. < https://www.mma.gov.br/biodiversidade/biodiversidadebrasileira >

Carstensen, B., Plummer, M., Laara, E., \& Hills, M. (2019). Epi: A Package for Statistical Analysis in Epidemiology. R package version 2.40. <https://CRAN.R-project.org/package=Epi>.

Costa, D. F., Silva, A. F., Farias, A. E. M., Brasil, A. W. L., Santos, F. A., Guilherme, R. F. G., Azevedo, S. S., \& Alves, C. J. (2016). Serological study of the Leptospira spp. infection in sheep and goats slaughtered in the State of Paraíba, semiarid of Northeastern Brazil. Semina: Ciências Agrárias, 37 (2), 819-828. https://doi.org/10.5433/1679-0359.2016v37n2p819

Costa, D. F., Silva, A. F., Brasil, A. W. L., Loureiro, A. P. P., Santos, F. A., Azevedo, S. S., Lilenbaum, W., \& Alves, C. J. (2017). Leptospirose em ovinos mestiços abatidos em uma região semiárida do Brasil. Ciência Rural, 47 (02), 1-6. https://doi.org/10.1590/0103-8478cr20160563 
Correia, W. F. B. (2012). Arquitetura e Clima no contexto do semiárido: estratégias bioclimáticas para cidade de Mata Grande - AL. Maceió, Alagoas, 170p. (Dissertação de Mestrado em Arquitetura e Urbanismo: Dinâmicas do Espaço Habitado. Faculdade de Arquitetura e Urbanismo, Universidade Federal de Alagoas)

da Costa, D. F., de Faria, P. J. A., Nogueira, D. B., de Oliveira Tolentino, L. H., Viana, M. P., da Silva, J. D., de Melo Vaz, A. F., dos Santos Higino, S. S., de Azevedo, S. S., \& Alves, C. J. (2019). Influence of breed on the clinical and hemato-biochemical parameters in sheep experimentally infected with Leptospira sp. Heliyon, 5 (10), e02720 https://doi.org/10.1016/j.heliyon.2019.e02720

Daipra, M. A., Corrêa, E. K., Rol, V. F., Xavier, E. G., Lopes, D. C. N., Lourenço, F. F., Zanusso, J. T., \& Rol, A. P. (2009). Uso de cal virgem para o controle de Salmonella spp. e Clostridium spp. em camas de aviário. Ciência rural, 39 (4), 1189-1194

Dorjee, S., Heuer, C., Jackson, R., West, D. M., Collins-Emerson, J. M., Midwinter, A. C., \& Ridler, A. L. (2008). Prevalence of pathogenic Leptospira spp. in sheep in a sheep-only abattoir in New Zealand. New Zealand Veterinary Journal, 56, 164-170

Ellis, W. A. (2015). Animal Leptospirosis. Current Topics in Microbiology Immunology, 387, 99-137

Faine, S., Adler, B., Bolin, C., \& Perolat, P. (1999). Leptospira and leptospirosis. (2a ed.), Melbourne: MediSci, 272p

Fernandes, C. E. (2009). Papel do ovino na cadeia epidemiológica da leptospirose pela Leptospira spp. sorovar Hardjo: fatores de risco que envolvem a infecção e transmissão entre ovinos e bovinos. São Paulo, São Paulo, 101p. (Dissertação de Mestrado em Sanidade, Segurança Alimentar e Ambiental no Agronegócio. Instituto Biológico)

Guilherme, R. F., Lima, A. M. C., Alves, J. R. A., Costa, D. F., Pinheiro, R. R., Alves, F. F. S., Azevedo, S. S., \& Alves, C. J. (2017). Characterization and typology of sheep and goat production systems in the State of Paraíba, a semi-arid region of northeastern Brazil. Semina: Ciências Agrárias, 38 (4), 21632178. http://doi.org/10.5433/1679-0359.2017v38n4p2163

Higino, S. S. S., Azevedo, S. S., Alves, C. J., Figueiredo, S. M., Silva, M. L. C. R., \& Batista, C. S. A. (2010). Frequency of leptospirosis in ovine slaughtered in Patos, Paraiba, Brazil. Arquivos Do Instituto Biologico (Sao Paulo), 77 (3), 525-527

IBGE. Instituto Brasileiro de Geografia e Estatística, BRASIL, 2017. Censo Agropecuário 2017: Resultados definitivos. https://censoagro2017.ibge.gov.br /templa tes/censo_agro/resultadosagro/pecuaria.html?localidade=0\&tema $=75674$

IBGE. Instituto Brasileiro de Geografia e Estatística, BRASIL, 2019. Pesquisa da Pecuária Municipal. https://sidra.ibge.gov.br/tabela/3939

Kich, J. D., Mores, N., Piffer, I. A., Coldebella, A., Amaral, A., Ramminger, L., \& Cardoso, M. (2005). Fatores associados à soroprevalência de Salmonella em rebanhos comerciais de suínos. Ciência Rural, 35 (2), 398-405. https://doi.org/10.1590/s0103-84782005000200024

Leal, I. R., da Silva, J. M. C., Tabarelli, M., \& Lacher Junior, T. E. (2005). Mudando o curso da conservação da biodiversidade na Caatinga do Nordeste do Brasil. Megadiversidade, 1 (1), 139-146

Lenharo, D. K., Santiago, M. E. B., \& Lucheis, S. B. (2012). Avaliação sorológica para leptospirose em mamíferos silvestres procedentes do parque zoológico municipal de Bauru, SP. Arquivos do Instituto Biológico, 79 (3), 333-341. https://doi.org/10.1590/s1808-16572012000300003

Martins, G., \& Lilenbaum, W. (2014). Leptospirosis in sheep and goats under tropical conditions. Tropical Animal Health and Production, 46, 11-17

Morais, D. A., Santos Junior, D. A., Nunes, B. C., Costa, D. F., Viana, M. P., Silva, J. D., Higino, S. S. S., Azevedo, S. S., \& Alves, C. J. (2019). Leptospirosis in donkeys (Equus asinus) destined for slaughter and export. Semina: Ciências Agrarias, 40 (6), 3541-3552. https://doi.org/10.5433/16790359.2019v40n6Supl3p3541

Nogueira, D. B., da Costa, F. T. R., de Sousa Bezerra, C., Silva, M. L. C. R., da Costa, D. F., Viana, M. P., da Silva, J. D., Júnior, J. P. A., Malossi, C. D., Ullmann, L. S., Santos, C. S. A. B., Alves, C. J., \& de Azevedo, S. S. (2020). Use of serological and molecular techniques for detection of Leptospira sp. carrier sheep under semiarid conditions and the importance of genital transmission route. Acta Tropica, 207, 105497. https://doi.org/https://doi.org/10.1016/j.actatropica.2020.105497

OIE. World Organization for Animal Health, Leptospirosis, in: Manual of Diagnostic Tests and Vaccines for Terrestrial Animals. (2014). World Organization for Animal Health

Paes, A. C. (2016). Leptospirose canina. In: Megid J., Ribeiro M.G. \& Paes A.C. (Eds), Doenças Infecciosas em Animais de Produção e de Companhia, 356 377

Pimenta, C. L. R. M., Bezerra, C. S., Morais, D. A., Silva, M. L. C, R., Nogueira, D. B., Costa, D. F., Santos, C. S. A. B., Higino, S. S. S., Alves, C. J., \& Azevedo, S. S. (2019). Seroprevalence and predominant serogroups of Leptospira sp. In serological tests of ruminants in northeastern Brazil. Semina: Ciências Agrarias, 40 (4), 1513-1522. https://doi.org/10.5433/1679-0359.2019v40n4p1513

R CORE TEAM (2019). R: A language and environment for statistical computing. R Foundation for Statistical Computing, Vienna, Austria. https://www.Rproject.org/

Ribeiro, J. F., Bridgewater, S., Ratter, J. A., Sousa-Silva, J. C. (2005). Ocupação do bioma Cerrado e conservação da sua diversidade vegetal. In Scariot, A., Sousa-Silva, J. C., Felfili, J. M., (Org.). Cerrado: Ecologia, biodiversidade e conservação. Brasília: Ministério do Meio Ambiente, $385-399$

Romero-Vivas, C. M., Thiry, D., Rodríguez, V., Calderón, A., Arrieta, G., Máttar, S., Cuello, M., Levett, P. N., \& Falconar, A. K. (2013). Molecular serovar characterization of Leptospira isolates from animals and water in Colombia. Biomédica, 33, 179-184

Santos, P. J., Lima-Ribeiro, A. M. C., Oliveira, P. R., Santos, M. P., Junior, A. F., Medeiros, A. A., \& Tavares, T. C. F. (2012). Seroprevalence and risk factors for Leptospirosis in goats in Uberlândia, Minas Gerais, Brazil. Tropical Animal Health and Production, 44, 101-106 
Research, Society and Development, v. 10, n. 2, e5610212242, 2021

(CC BY 4.0) | ISSN 2525-3409 | DOI: http://dx.doi.org/10.33448/rsd-v10i2.12242

Silva, A. F., Farias, P. J. A., Silva, M. L. C. R., Araújo Júnior, J. P., Malossi, C. D., Ullmann, L. S., Costa, D. F., Higino, S. S. S., Azevedo, S. S., \& Alves, C. J. (2019). High frequency of genital carriers of Leptospira sp. in sheep slaughtered in the semi-arid region of northeastern Brazil. Tropical Animal Health and Production, 51 (1), 43-47. https://doi.org/10.1007/s11250-018-1657-9

Silva, R. C., Costa, V. M., Shimabukuro, F. H., Richini-Pereira, V. B., Menozzi, B. D., \& Langoni, H. (2012). Frequency of Leptospira spp. in sheep from Brazilian slaughterhouses and its association with epidemiological variables. Pesquisa Veterinária Brasileira, 32 (3), 194-198

Sousa, W. H. (2007). O Agronegócio da caprinocultura de corte no Brasil. Tecnologia \& Ciência Agropecuária, 1 (1), $51-58$

Souza, P. T., Salles, M. G. F., Costa, A. N. L., Carneiro, H. A. V., Souza, L. P., Rocha, D. R., \& Araújo, A. A. (2015). Perfil hematológico de cabras Sa anen e mestiças (1/2 Saanen e 1/2 Anglo-nubiana) criadas em clima tropical do Ceará. Pesquisa Veterinária Brasileira, 35(1), 99-104. https://doi.org/10.1590/S0100736 X2015000100019

Spickler, A. R., \& Leedom Larson, K. R. (2013). Leptospirosis. The Center for Food Security \& Public Health. Iowa State University. <http://www.cfsph.iastate.edu/DiseaseInfo/factsheets.php >.

Thrusfield, M. (2007). Veterinary epidemiology, (3a ed.), Blackwell Science, 624p

Viana, M. P., Medeiros, A. R., \& Souza, B. B. de. (2012). Efeitos do estresse térmico sobre a fisiologia, produção e reprodução de caprinos. Agropecuária Científica do Semiárido, 9 (4) 01-08

Wolf, J., Gouvea, A., Silva, E. R. L., Potrich, M., \& Appel, A. (2014). Métodos físicos e cal hidratada para manejo do cascudinho dos aviários. Ciencia Rural, 44 (1), 161-166. https://doi.org/10.1590/s0103-84782014000100026

Zeileis, A., \& Hothorn, T. (2002). Diagnostic Checking in Regression Relationships. R News, 2 (3), 7-10. <https://CRAN.R-project.org/doc/Rnews/>.

Zuerner, R. L. (2005). Laboratory maintenance of pathogenic Leptospira. Current Protocols in Microbiology, 12, 12E.1 